\title{
Three cases of $\mathrm{Hb} \mathrm{Q}-\mathrm{H}$ disease found in a Cantonese family
}

\author{
CHAOHUI HU, LING ZHANG, JIANGHU PAN, ZENGYU ZENG, \\ SAIXIANG ZHEN, JU FANG and QINGYI ZHU
}

Guangzhou Kingmed Center for Clinical Laboratory, Guangzhou 510330, P.R. China

Received September 30, 2010; Accepted December 22, 2010

DOI: $10.3892 / \mathrm{mmr} .2011 .419$

\begin{abstract}
Hemoglobin (Hb) Q-Thailand, also known as G-Taichung, Mahidol, Kurashiki-I and Asabara, is an $\alpha$-globin chain variant that results from a point mutation $(\mathrm{GAC} \rightarrow \mathrm{CAC} ; \mathrm{Asp} \rightarrow \mathrm{His})$ at codon 74 of the $\alpha 1$-globin gene on chromosome $16 \mathrm{p}$ with a leftward single $\alpha$-globin gene deletion $\left(-\alpha^{4.2}\right)$. Co-inheritance of $\mathrm{Hb} \mathrm{Q}$-Thailand with $\alpha$-thalassemia (mainly -_SEA) results in thalassemia intermedia, termed $\mathrm{Hb} \mathrm{Q}-\mathrm{H}$ disease. The aim of the present study was to identify $\mathrm{Hb} \mathrm{Q}-\mathrm{H}$ disease in a Cantonese family. The presence of the $\mathrm{Hb}$ variant was confirmed by cellulose acetate electrophoresis. DNA analysis, based on polymerase chain reaction and sequencing, was developed to identify the $\alpha^{\mathrm{Q}-T h a i l a n d}$ mutation and common $\alpha$-thalassemia gene deletions. Three cases of $\mathrm{Hb} \mathrm{Q}-\mathrm{H}$ disease and two $\mathrm{Hb} \mathrm{Q}-\mathrm{Thailand}$ carriers were found in the family. The 3-day-old proband with $\mathrm{Hb} \mathrm{Q}-\mathrm{H}$ disease did not show anemia ( $\mathrm{Hb} 144 \mathrm{~g} / \mathrm{l}$ ), having $25.47 \% \mathrm{Hb} \mathrm{F}^{\mathrm{Q}}$ $\left(\alpha_{2} \gamma_{2}\right)$ in the total $\mathrm{Hb}$; the other two cases of $\mathrm{Hb} \mathrm{Q}-\mathrm{H}$ disease manifested mild-to-moderate anemia. None required regular transfusions.
\end{abstract}

\section{Introduction}

Hemoglobin (Hb) Q-Thailand, also known as G-Taichung, Mahidol, Kurashiki-I and Asabara, is often found in Thai, Chinese, and Japanese individuals (1). The hemoglobin ( $\mathrm{Hb}$ ) Q-Thailand mutation is an $\alpha$-globin chain variant that results from a point mutation ( $\mathrm{GAC} \rightarrow \mathrm{CAC}$; $\mathrm{Asp} \rightarrow \mathrm{His}$ ) at codon 74 of the $\alpha 1$-globin gene on chromosome 16p (2,3). Individuals heterozygous for $\mathrm{Hb} \mathrm{Q}-$ Thailand usually show slight red cell microcytosis, since the mutation is invariably linked to $\left(-\alpha^{4.2}\right)$ (1). $\mathrm{Hb} \mathrm{Q}-\mathrm{H}$ disease is caused by the co-inheritance of $\mathrm{Hb}$ Q-Thailand and $\alpha^{0}$-thalassemia (mainly -_SEA), and presents with marked microcytosis, chronic hemolytic anemia associated with jaundice and hepatosplenomegaly (4). Affected individuals show a thalassemic blood shape similar to that observed in $\mathrm{Hb}$

Correspondence to: Dr Chao-Hui Hu, Guangzhou Kingmed Center for Clinical Laboratory, Guangdong, Guangzhou 510330, P.R. China E-mail: huzh@kingmed.com.cn

Key words: hemoglobin variant, hemoglobin Q-H disease
$\mathrm{H}$ disease, but $\mathrm{Hb}$ analysis reveals the absence of $\mathrm{Hb} \mathrm{A}$, with $\mathrm{Hb} \mathrm{Q}-\mathrm{Thailand}$ being the predominant fraction (4).

$\mathrm{Hb} \mathrm{Q}-\mathrm{H}$ is a rarely occurring disease; to date, all identified individuals have been Chinese or of Chinese origin. Here, we reported three cases of this disorder in a Cantonese family.

\section{Materials and methods}

Subjects and hematological analysis. The proband was a 3-day newborn who presented for thalassemia screening at the Guangzhou Kingmed Center for Clinical Laboratory. According to the specific results of hematological analysis, the proband was diagnosed as a homozygous $\mathrm{Hb} \mathrm{H}$ with an unknown $\mathrm{Hb}$ variant. Blood samples with EDTA were collected from the proband and his family members and immediately sent at $4^{\circ} \mathrm{C}$ to the Hematology and Molecular Laboratory for further analysis. Hematological data were collected on an automated blood cell counter $\left(\mathrm{AC} \cdot \mathrm{T}^{\mathrm{TM}} 5 \mathrm{diff}\right.$; Beckman Coulter, USA). Electrophoresis of hemoglobins was carried out in agar using a Spife 3000 electrophoresis system (Helena Laboratories, USA).

DNA analysis. Genomic DNA was extracted from peripheral blood leukocytes with the Genomic DNA Mini-Prep kit (Decipher Bioscience Shenzhen Ltd., China) as previously described (5). $\alpha$-thalassemia-1 (SEA type) and $\alpha$-thalassemia-2 $\left(-\alpha^{3.7}\right.$ and $\left.-\alpha^{4.2}\right)$ were identified by gap-PCR with the $\alpha$-thalassemia genotype detection kit (Decipher Bioscience Shenzhen Ltd.) in a KP-TC48 DNA Thermal Cycler (Chaozhou Hybribio Biotechnology, China). Polymerase chain reaction (PCR) was performed under the following conditions: DNA was denatured at $96^{\circ} \mathrm{C}$ for $15 \mathrm{~min}$, followed by 35 cycles at $98^{\circ} \mathrm{C}$ for $45 \mathrm{sec}$, annealing at $60^{\circ} \mathrm{C}$ for $90 \mathrm{sec}$, extension at $72^{\circ} \mathrm{C}$ for $150 \mathrm{sec}$ and a final extension step for $5 \mathrm{~min}$. The PCR products were separated by electrophoresis on $2.0 \%$ agarose gel.

The $\alpha 1$-globin gene was amplified with previously described primers (6). The 50- $\mu 1$ PCR reaction mixture contained $0.1 \mu \mathrm{g}$ DNA, 25 pmol primers, $200 \mu \mathrm{mol}$ dNTPs and 2.5 units Taq DNA polymerase (Shanghai Sangon Biological Engineering Technology \& Services Co., Ltd., China) in $10 \mathrm{mmol} / 1$ Tris- $\mathrm{HCl}(\mathrm{pH} 8.0), 50 \mathrm{mmol} / \mathrm{l} \mathrm{KCl}$ and $3 \mathrm{mmol} / \mathrm{l} \mathrm{MgCl}_{2}$. The amplification reaction was carried out at $95^{\circ} \mathrm{C}$ for $3 \mathrm{~min}, 59^{\circ} \mathrm{C}$ for $1 \mathrm{~min}$ and $72^{\circ} \mathrm{C}$ for $1 \mathrm{~min}$ for 30 cycles in the KP-TC48 DNA Thermal Cycler. The PCR products were analyzed on the ABI 377 DNA Sequencer (Applied Biosystems, CA, USA). 
Table I. Hematological findings for the family members.

\begin{tabular}{|c|c|c|c|c|c|c|}
\hline Parameter & 1 & 2 & 3 & 4 & 5 & 6 \\
\hline Gender & Male & Female & Female & Female & Male & Male \\
\hline Age & 47 years & 45 years & 16 years & 13 years & 11 years & 3 days \\
\hline RBC (1012/1) & 5.69 & 2.84 & 4.51 & 4.72 & 5.38 & 6.30 \\
\hline $\mathrm{Hb}(\mathrm{g} / \mathrm{dl})$ & 155.00 & 64.00 & 85.00 & 126.00 & 105.00 & 144.00 \\
\hline MCV (fl) & 79.00 & 71.00 & 63.00 & 77.00 & 65.00 & 75.00 \\
\hline $\mathrm{MCH}(\mathrm{pg})$ & 27.20 & 22.60 & 18.90 & 26.70 & 19.50 & 22.90 \\
\hline $\operatorname{HCT}(\%)$ & 0.45 & 0.20 & 0.286 & 0.365 & 0.348 & 0.471 \\
\hline RDW $(\%)$ & 13.30 & 14.90 & 17.90 & 12.30 & 17.00 & 19.80 \\
\hline $\mathrm{Hb} \mathrm{A}_{2}(\%)$ & 1.86 & 2.57 & 0.47 & 1.81 & 0.33 & 0.13 \\
\hline $\mathrm{Hb} \mathrm{A}(\%)$ & 65.54 & 97.43 & 1.18 & 66.34 & 3.81 & 3.83 \\
\hline Hb Q-Thailand (\%) & 32.60 & 0.00 & 81.58 & 31.85 & 80.81 & $\begin{array}{l}32.50\left(\alpha^{\mathrm{Q}_{2}} \beta_{2}\right) \\
25.47\left(\alpha_{2}^{\mathrm{Q}} \gamma_{2}\right)\end{array}$ \\
\hline $\mathrm{Hb} \mathrm{H}+\mathrm{H}$ Bart's $(\%)$ & 0.00 & 0.00 & 16.77 & 0.00 & 15.05 & 37.97 \\
\hline Genotype & $\alpha \alpha /-\alpha^{4.2-Q}$ & $\alpha \alpha /--\operatorname{SEA}$ & $-{ }_{-} \mathrm{SEA} /-\alpha^{4.2-\mathrm{Q}}$ & $\alpha \alpha /-\alpha^{4.2-Q}$ & $-{ }_{-} \mathrm{SEA} /-\alpha^{4.2-\mathrm{Q}}$ & $-{ }_{-} \mathrm{SEA} /-\alpha^{4.2-\mathrm{Q}}$ \\
\hline
\end{tabular}

1, father; 2, mother; 3, elder brother; 4, young sister; 5, elder sister; 6, the proband (newborn); RBC, red blood cell count; Hb, hemoglobin; $\mathrm{MCV}$, mean corpuscular volume; $\mathrm{MCH}$, mean corpuscular hemoglobin; MCHC, mean corpuscular hemoglobin concentration; HCT, hematocrit; RDW, red blood cell distribution width.

A

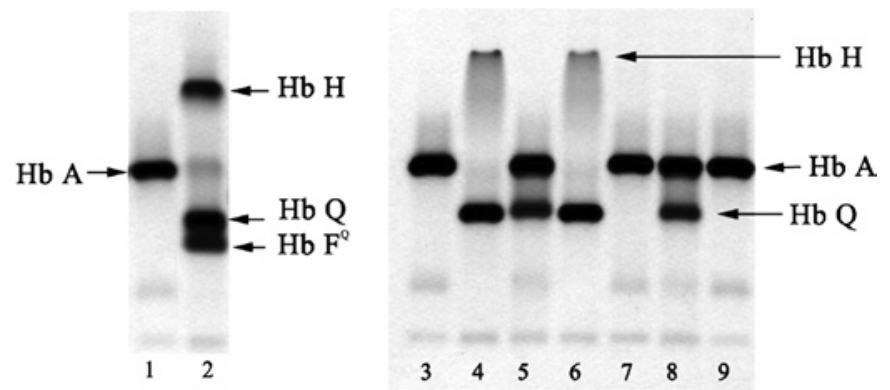

Figure 1. Hemoglobin analysis of the proband and family members with agarose electrophoresis. (A) 1, Normal control; 2, the proband (3-day newborn); (B) 3, Normal control; 4, elder brother; 5, young sister; 6, elder sister; 7, mother; 8 , father; 9 , normal control.

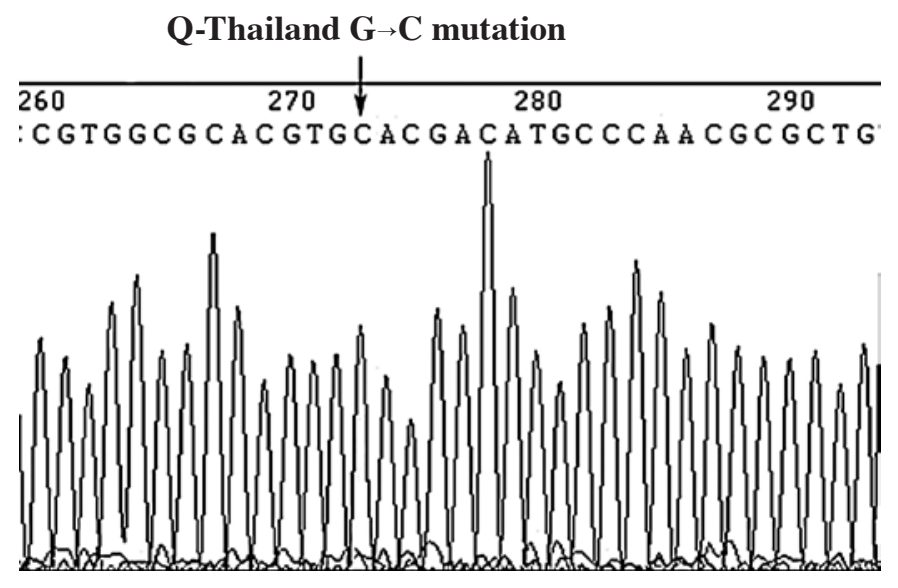

Figure 2. DNA sequence analysis of amplified $\alpha 1$-globin gene from the proband and his family members. The downward arrow indicates the $\mathrm{G} \rightarrow \mathrm{C}$ substitution at codon 74 of the $\alpha 1$-globin gene.

\section{Results}

Three cases of Hb Q-H disease and two Hb Q-Thailand carriers were found in the family. The hematological data for the family are summarized in Table I. The Hb, mean corpuscular volume and mean corpuscular hemoglobin values of the family members with $\mathrm{Hb} \mathrm{Q}-\mathrm{H}$ were lower than normal, except in the 3-day-old newborn, which is consistent with previous reports $(2,3,7)$. The proband had $\mathrm{Hb} \mathrm{Q}\left(\alpha_{2}{ }_{2} \beta_{2}\right)$ and $\mathrm{Hb} \mathrm{FQ}^{\mathrm{Q}}\left(\alpha_{2} \gamma_{2}\right)$ bands as revealed by agar electrophoresis (Fig. 1A), but no anemia $(\mathrm{Hb}, 144 \mathrm{~g} / \mathrm{l})$, with a $25.47 \% \mathrm{Hb} \mathrm{F}^{\mathrm{Q}}\left(\alpha_{2}^{\mathrm{Q}} \gamma_{2}\right)$ in the total $\mathrm{Hb}$. The results of electrophoresis of samples from the family members are shown in Fig. 1B. Gap-PCR studies for $\alpha$-thalassemia indicated that the proband, his elder brother and elder sister were $-\alpha^{4.2} /--$ SEA , his young sister and father were $\alpha \alpha /-\alpha^{4.2}$, and his mother was $\alpha \alpha /$-- SEA. DNA sequence analysis of the amplified $\alpha 1$-globin gene indicated that all family members, except for the mother, had a point mutation $(\mathrm{GAC} \rightarrow \mathrm{CAC}$; $\mathrm{Asp} \rightarrow \mathrm{His}$ ) at codon 74 of the $\alpha 1$-globin gene and were carriers of $\mathrm{Hb}$ Q-Thailand (Fig. 2). The proband, his elder brother and elder sister had $\mathrm{Hb} \mathrm{Q}-\mathrm{H}$ disease (- $\left.\alpha^{4.2-\mathrm{Q} /--}{ }^{\mathrm{SEA}}\right)$.

\section{Discussion}

$\mathrm{Hb}$ Q-Thailand $(\alpha 74 \mathrm{Asp} \rightarrow \mathrm{His})$ is an abnormal $\mathrm{Hb}$ variant that was first identified in a Chinese family (8). All carriers of the $\mathrm{Hb}$ Q-Thailand gene in previous reports are Chinese or of Chinese origin $(2,3,7)$. Patients heterozygous for the $\mathrm{Hb} \mathrm{Q}-\mathrm{Thailand}$ mutation possess a $4.2-\mathrm{kb}$ deletion at chromosome $16 \mathrm{p}$ of the $\alpha$-globin gene, and have mild red cell microcytosis $(2,3,7)$. It is well known that the high incidence area of $\mathrm{Hb} \mathrm{Q}-$ Thailand is also the high incidence area of thalassemia, and co-inheritance of $\mathrm{Hb} \mathrm{Q}$-Thailand with $\alpha$-thalassemia (mainly --_SEA) results in thalassemia intermedia, termed $\mathrm{Hb} \mathrm{Q}-\mathrm{H}$ disease. 
In the present study, we identified three cases of $\mathrm{Hb} \mathrm{Q}-\mathrm{H}$ disease in a family from the Canton Province of China. The father of the family carried the Q-Thailand mutation and had - $\alpha^{4.2} \alpha$-thalassemia with slightly altered hematological parameters and no clinical symptoms (Hb, 15.5g/l; MCV, 79fl). The $\mathrm{Hb} \mathrm{Q}-\mathrm{Thailand}$ variant was stable and had normal oxygen affinity. The mother had -- SEA thalassemia.

Clinically, patients with $\mathrm{Hb} \mathrm{Q}-\mathrm{H}$ disease are categorized as having deletional $\mathrm{Hb} \mathrm{H}$ disease, and genetic counseling for $\mathrm{Hb}$ $\mathrm{Q}-\mathrm{H}$ disease is similar to that for deletional $\mathrm{Hb} \mathrm{H}$ (9). Three of the four children in the present study - the proband, his elder brother and elder sister - had $\mathrm{Hb} \mathrm{Q}-\mathrm{H}$ disease. The 3-day-old proband did not have anemia $(\mathrm{Hb}, 144 \mathrm{~g} / \mathrm{l})$, since there was $25.47 \% \mathrm{Hb} \mathrm{FQ}^{\mathrm{Q}}\left(\alpha_{2}^{\mathrm{Q}} \gamma_{2}\right)$ in the total Hb. The other two cases of $\mathrm{Hb}$ $\mathrm{Q}-\mathrm{H}$ disease manifested mild-to-moderate anemia (elder brother, $105 \mathrm{~g} / \mathrm{l}$; elder sister, $85 \mathrm{~g} / \mathrm{l}$ ). None of the three family members affected by $\mathrm{Hb} \mathrm{Q}-\mathrm{H}$ disease required regular transfusions.

\section{References}

1. Singsanan S, Karnpean R, Fucharoen G, Sanchaisuriya K Sae-Ung N and Fucharoen S: Hemoglobin Q-Thailand related disorders: Origin, molecular, hematological and diagnostic aspects. Blood Cells Mol Dis 45: 210-214, 2010.
2. Lie-Injo LE, Dozy AM, Kan YW, Lopes M and Todd D: The alpha-globin gene adjacent to the gene for HbQ-alpha 74 Asp replaced by His is deleted, but not that adjacent to the gene for HbG-alpha 30 Glu replaced by Gln; three-fourths of the alphaglobin genes are deleted in HbQ-alpha-thalassemia. Blood 54: 1407-1416, 1979.

3. Higgs DR, Hunt DM, Drysdale HC, Clegg JB, Pressley L and Weatherall DJ: The genetic basis of $\mathrm{Hb}$ Q-H disease. $\mathrm{Br} \mathrm{J}$ Haematol 46: 387-400, 1980.

4. Tan J, Tay JS, Wong YC, Kham SK, Bte Abd Aziz N, Teo SH and Wong HB: Molecular analysis of $\mathrm{Hb} \mathrm{Q}-\mathrm{H}$ disease and $\mathrm{Hb}$ Q-E in a Singaporean family. Southeast Asian J Trop Med Public Health 26 (suppl 1): 252-256, 1995.

5. Wang PP, Lin M, Wu JG, Wang XY and Yang LY: Three cases of the hemoglobin G-Chinese variant detected in patients of southern Chinese origin. Mol Med Rep 3: 459-461, 2010.

6. Ameri A, Fairbanks VF, Yanik GA, Mahdi F, Thibodeau SN, McCormick DJ, Boxer LA and McDonagh KT: Identification of the molecular genetic defect of patients with methemoglobin M-Kankakee (M-Iwate), alpha87 (F8) His --> Tyr: evidence for an electrostatic model of alphaM hemoglobin assembly. Blood 94: 1825-1826, 1999.

7. Li D, Liao C, Xie X, Zhong H and Li J: Four cases of Hb Q-H disease found in Southern China. Hemoglobin 31: 109-111, 2007.

8. Blackwell RQ and Liu CS: Hemoglobin G Taichung: alpha-74 Asp leads to His. Biochim Biophys Acta 200: 70-75, 1970.

9. Leung KF, Ma ES, Chan AY and Chan LC: Clinical phenotype of Haemoglobin Q-H disease. J Clin Pathol 57: 81-82, 2004. 